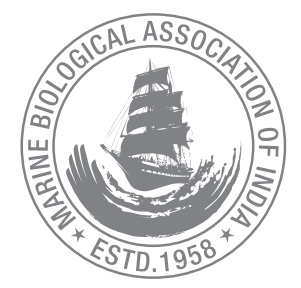

\title{
Length-weight relationship of Thunnus albacares, landed along north Andhra Pradesh
}

\author{
M. Satish Kumar, Shubhadeep Ghosh*, K. Sreeramulu', V. U. Mahesh, M. V. Hanumantha Rao \\ and Prathibha Rohit \\ Regional Centre of ICAR-CMFRI, Pandurangapuram, Visakhapatnam - 530 003, Andhra Pradesh, India. \\ 'Department of Zoology, Andhra University, Visakhapatnam - 530 003, Andhra Pradesh, India.
}

*Correspondence e-mail: subhadeep_1977@yahoo.com

Received: 15 Oct 2018 Accepted: 16 April 2019 Published: 30 June 2019

Original Article

\begin{abstract}
The length and weight of Thunnus albacares (Bonnaterre, 1788) off north Andhra Pradesh during 2012 - 2015 were studied and the length-weight relationship was found out. A total of 3,617 specimens were analysed and the reported length range was $18 \mathrm{~cm}$ to $186 \mathrm{~cm}$ fork length. In the fishery, peak landings of size classes $41-50 \mathrm{~cm}$ and $111-120 \mathrm{~cm}$ were observed. Annual mean lengths ranged from $62.7 \mathrm{~cm}$ to $92.7 \mathrm{~cm}$. The highest mean length of 92.7 $\mathrm{cm}$ was recorded in 2014 and the lowest mean length of $62.7 \mathrm{~cm}$ was recorded in 2015. Length-weight relationship was not found to differ significantly between sexes and the pooled relation was $\log W=\log 0.016+2.996 \log \mathrm{L}$. The growth pattern observed was isometric.
\end{abstract}

Keywords: Length, north Andhra Pradesh, Thunnus albacares, weight

\section{Introduction}

Tunas are landed in substantial amounts at Visakhapatnam, making it one of the major tuna landing centres in the country. Thunnus albacares (yellowfin tuna) contributes the most to the tuna landings. It is exclusively landed by catamarans and converted long liners and a very minor quantity is landed by trawl nets and bottom-set gillnets operated at depths nearing $150 \mathrm{~m}$. Thunnus albacares is mostly exploited in the oceanic waters beyond the depths of $200 \mathrm{~m}$ off Visakhapatnam using hooks and lines and trolls operated mostly from non mechanized traditional craft (catamaran). Nearly 1200 such crafts operate from Visakhapatnam for hunting yellowfin tuna with their fishing operations extending to deeper waters of 200-300 meters depth towards the northern Andhra Pradesh and to beyond Kakinada, Andhra Pradesh.

Length-weight relationship studies are very much helpful to study the growth of fish stocks, population dynamics and will be of great help in determining one variable when the other variable is known for any particular species. It may also offer indications on taxonomic differences and the developmental physiological events occurred in the life history, such as metamorphosis and onset of maturity (Thomas et al., 2003). In addition, it can 
help in distinguishing populations, if any, spatially (Beverton and Holt, 1957). The weight of a normal fish has a curvilinear relationship with body length.

Though there are quite a few studies on the length and weight relation for Thunnus albacares from various sections of the Indian EEZ (Madan Mohan et al., 1985; John and Reddy, 1989; Sudarsan et al., 1991; John and Sudarsan, 1993; Pillai et al., 1993; John, 1995; Pandian et al., 2007; Abdussamad et al., 2008; Sivadas, 2009), most of them are at least a decade back. Moreover, northern Andhra Pradesh leads the country in the annual landings for Thunnus albacares, however studies on length and weight relation from this region are scarce and are limited to only a couple of studies (Rohit et al., 2009; 2012). The present study, therefore aims at testing the relationship between length and weight of Thunnus albacares off north Andhra Pradesh.

\section{Material and methods}

A total of 3,617 specimens of Thunnus albacares were collected randomly from weekly observation made at Lawsons Bay, Visakhapatnam Outer Harbour and Pudimadaka Beach, the important traditional yellowfin tuna landing centres at Visakhapatnam and from Kakinada Fishing Harbor, Dummulapeta and Bhairavapalem, the important fish landing centres at Kakinada during 2012 - 2015. Samples were collected randomly and were measured for the fork length of each fish in centimeters $(\mathrm{cm})$. Length of specimens ranged from $18.0 \mathrm{~cm}$ to $186.0 \mathrm{~cm}$. The total wet body weight of the fish was taken by means of an electronic balance and was recorded in grams (grams to $0.01 \mathrm{~g}$ precision). Length-weight relationship was calculated as $W=\mathrm{aL}^{\mathrm{b}}$ (Le Cren, 1951) from 1414 specimens, separately for both sexes and indeterminates. Length and weight ranges for samples used for estimating the relationship varied from $23 \mathrm{~cm}$ to $171 \mathrm{~cm}$ and from $157 \mathrm{~g}$ to $80.4 \mathrm{~kg}$. Significant differences in the slopes of the regression lines for males, females and indeterminates were ascertained by Analysis of Covariance ANACOVA (Snedecor and Cochran, 1967). The parameters $a$ and $b$ were estimated by the least-square method from logarithmically transformed data, and the association degree between weightlength variables was calculated by the determination coefficient $\left(r^{2}\right)$. The statistical significance level of $r^{2}$ and $95 \%$ confidence limits of the parameters $a$ and $b$ were estimated. Students - $t$ test was performed to check the nature of the growth, to observe on whether, the value of the exponent (b) differed significantly from the isometric value of 3 or not.

\section{Results}

\section{Length Frequency distribution}

The length frequency distribution of different size ranges of Thunnus albacares for the year 2012 of the study period is shown in Fig. 1. Specimens from $31-40 \mathrm{~cm}$ and $71-80 \mathrm{~cm}$ length range dominated the fishery and the highest length range observed was 161-170 cm. Juveniles were exploited during the months of July, August and December. In 2013, fishery commenced from $41-50 \mathrm{~cm}$ size ranges with minor changes in juvenile catch composition (Fig. 2). Throughout the year, all size classes were reflected more or less in equal numbers with peak landings of size classes $41-50 \mathrm{~cm}$ and $111-120 \mathrm{~cm}$. Compared to 2012 and 2013, there was a decline in juvenile catches in 2014 and adults decreased in 2015 (Figs. 3 and 4). During 2014 and 2015, more catches were observed from length classes above $51-60 \mathrm{~cm}$. In all the years, all length ranges were exploited with a single peak in the length frequency observed at a size range of $41-50 \mathrm{~cm}$, which dominated the fishery. Overall exploitation of all length groups was observed throughout the study period (Fig. 5).

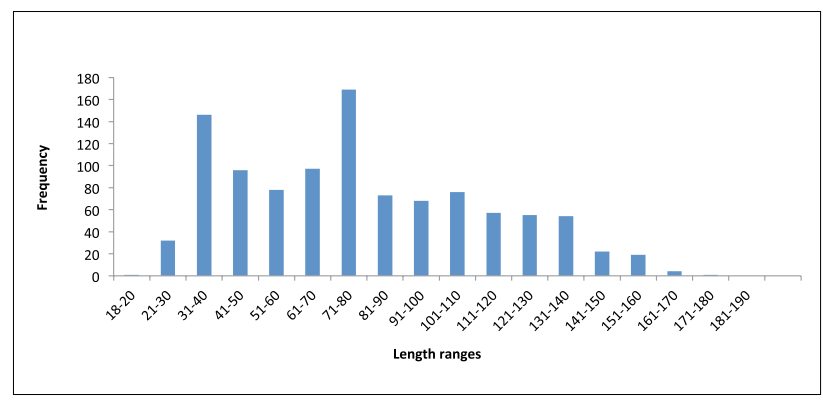

Fig. 1. Length frequency of yellowfin tuna landed off northern Andhra Pradesh during 2012

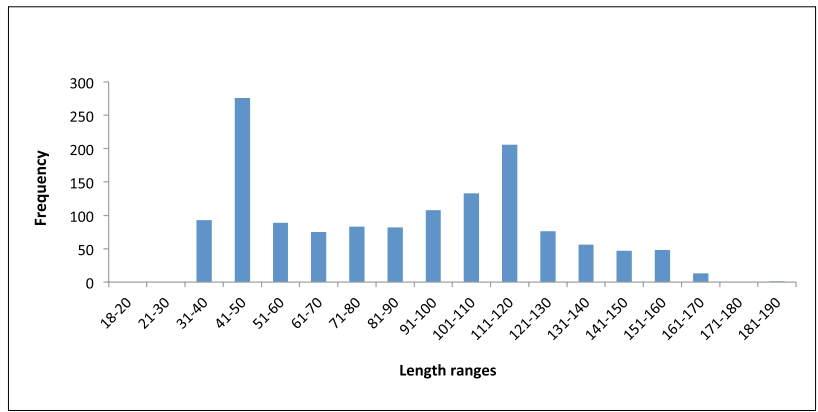

Fig. 2. Length frequency of yellowfin tuna landed off northern Andhra Pradesh during 2013

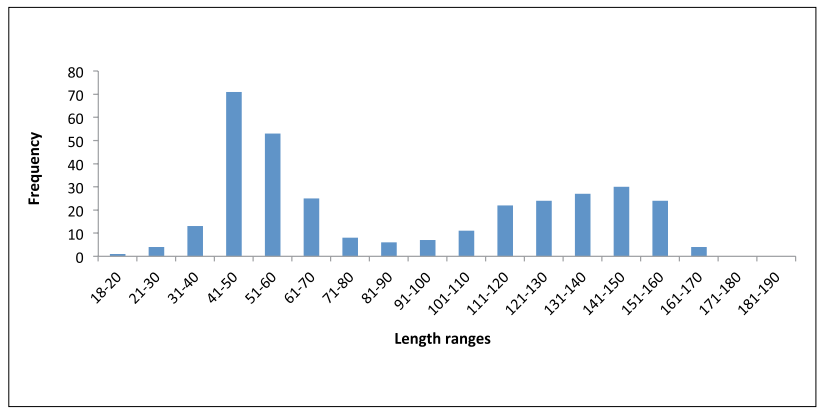

Fig. 3. Length frequency of yellowfin tuna landed off northern Andhra Pradesh during 2014 


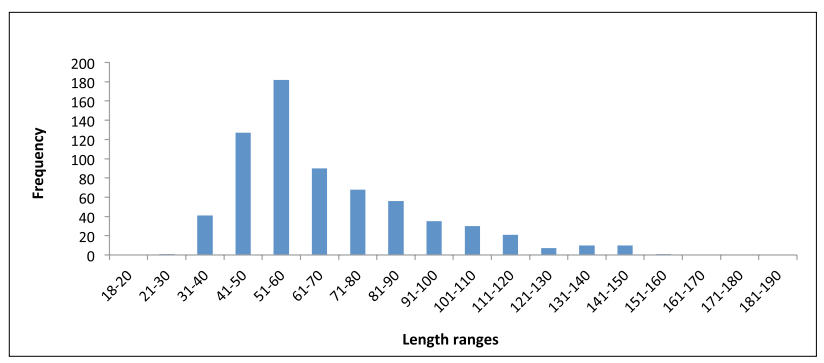

Fig. 4. Length frequency of yellowfin tuna landed off northern Andhra Pradesh during 2015

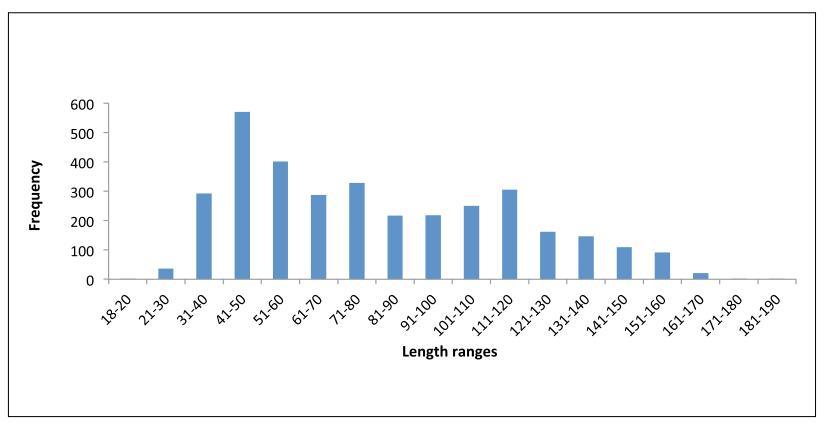

Fig. 5. Pooled length frequency of yellowfin tuna landed off northern Andhra Pradesh during 2012-2015

\section{Mean Length}

The annual mean lengths $(\mathrm{cm})$ ranged from $62.7 \mathrm{~cm}$ to $92.7 \mathrm{~cm}$. A gradual increase in mean lengths was observed from 2012 to 2014 with the highest mean length of $92.7 \mathrm{~cm}$ recorded in 2014 and the lowest mean length of $62.7 \mathrm{~cm}$ recorded in
2015. Highest mean lengths were recorded during OctoberApril. Detailed annual and monthly mean lengths are depicted in Table 1.

\section{Length-Weight Relationships}

The following equations for males and females separately were obtained.

Male: $\log W=\log 0.017+2.980 \log L\left(r^{2}=0.97\right)$ $(95 \%$ C. I.) $(n=730)$ (Fig. 6)

Female: $\log W=\log 0.015+3.005 \log L\left(r^{2}=0.98\right)$ $(95 \%$ C. I.) $(\mathrm{n}=502)$ (Fig. 7)

Pooled: $\log W=\log 0.016+2.996 \log L\left(r^{2}=0.97\right)(95 \%$ C. I. $)$ $(n=1414)$ (Fig. 8)

Indeterminate: $\log W=\log 0.016+3.000 \log L\left(r^{2}=0.95\right)$ $(95 \%$ C. I.) $(\mathrm{n}=182)$ (Fig. 9)

Analysis of covariance (ANACOVA) was performed to test the significant difference in the length-weight relationship between the sexes and the relationship was found to be not significant.

The length-weight relationship for males, females and indeterminates were found to be not significantly different at $5 \%$ level. Slopes of the regression relation for males $\left(t_{\text {cal }}\right.$ $\left.=1.01 ; \mathrm{t}_{\text {cit } 0.05}=1.96\right)$, females $\left(\mathrm{t}_{\text {cal }}=0.29 ; \mathrm{t}_{\text {crit } 0.05}=1.96\right)$ and indeterminates $\left(\mathrm{t}_{\text {cal }}=0.02 ; \mathrm{t}_{\text {cit } 0.05}=1.96\right)$ were not significantly different from the statistical value of 3 indicating isometric growth. Therefore, a pooled equation for the population was arrived at which was: $\log W=\log 0.016+2.996 \log L\left(r^{2}=\right.$ 0.97) (95\% C. I.).

Table 1. Annual and Monthly Mean Lengths during 2012-2015

\begin{tabular}{|c|c|c|c|c|c|c|}
\hline \multirow[b]{2}{*}{ Months } & \multicolumn{6}{|c|}{ Mean Length $(\mathrm{cm})$} \\
\hline & 2012 & 2013 & 2014 & 2015 & Mean & SE \\
\hline January & 116.8 & 95.9 & 140.0 & 56.2 & 102.2 & 17.8 \\
\hline February & 89.7 & 88.1 & 55.5 & 61.9 & 73.8 & 8.8 \\
\hline March & 93.5 & 113.8 & 114.8 & 37.4 & 89.9 & 18.2 \\
\hline April & 118.2 & 96.4 & 87.7 & 86.8 & 97.3 & 7.3 \\
\hline May & 74.4 & 88.9 & 83.2 & 67.4 & 78.5 & 4.7 \\
\hline June & 88.9 & 91.0 & 63.4 & 46.0 & 72.3 & 10.8 \\
\hline July & 55.5 & 65.3 & 55.2 & 64.6 & 60.1 & 2.8 \\
\hline August & 59.6 & 63.6 & 62.6 & 73.3 & 64.8 & 3.0 \\
\hline September & 78.4 & 47.1 & 119.9 & 53.9 & 74.8 & 16.5 \\
\hline October & 69.6 & 96.4 & 113.0 & 87.2 & 91.6 & 9.1 \\
\hline November & 72.0 & 108.7 & 78.6 & 59.6 & 79.7 & 10.4 \\
\hline December & 43.5 & 142.9 & 138.8 & 70.1 & 98.8 & 24.9 \\
\hline Annual & 80.0 & 91.5 & 92.7 & 63.7 & 82.0 & 6.7 \\
\hline
\end{tabular}




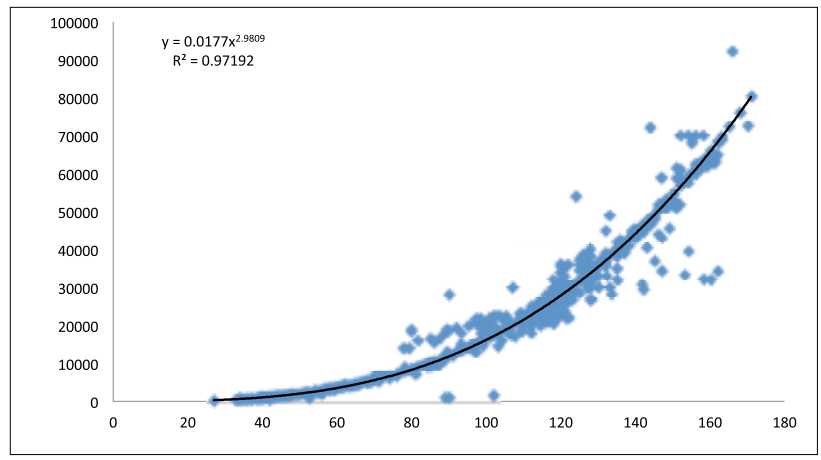

Fig. 6. Length-Weight relationship for males of Thunnus albacares

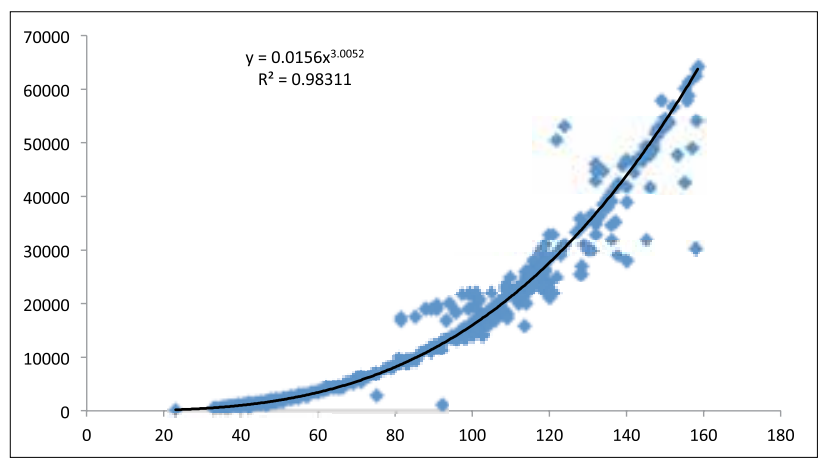

Fig. 7. Length-Weight relationship for females of Thunnus albacares

\section{Discussion}

The length range of 18-186 $\mathrm{cm}$ observed during the present study is almost similar and a little wider to that reported earlier from different sectors of Indian EEZ and other oceans. Madan Mohan et al. (1985) and Sivadas (2009) had reported length ranges from commercial vessels for male and female separately from different sectors of Indian EEZ which were comparatively lesser than the values obtained in the present study. Pillai et al. (1993) reported a length range of 32-128 cm in the Lakshadweep waters and John and Sudarshan (1993) recorded a length range of $60-180 \mathrm{~cm}$ in the oceanic waters of the Indian seas. In the oceanic sector of EEZ of India, based on the longline catches of survey vessels of FSI, various authors (John and Reddy, 1989; Sudarshan et al., 1991; John, 1995) reported length ranges of $48-181 \mathrm{~cm}$ fork length which is narrower than that of the present study. Rohit et al. $(2009,2012)$ collected specimens of $30-190 \mathrm{~cm}$ and $20-185 \mathrm{~cm}$ fork lengths from the same region as of the present study, and reported a mean length of 106 $\mathrm{cm}$ and $101.9 \mathrm{~cm}$, in tune with the present findings. Smaller length classes of Thunnus albacares in the Indian waters were landed by trawls and gillnets only. Large sized individuals were contributed by longlines and hooks and lines which were reported as $190 \mathrm{~cm}(103 \mathrm{~kg}), 156 \mathrm{~cm}(64 \mathrm{~kg})$ and $125.9 \mathrm{~cm}(36$ $\mathrm{kg}$ ) by Rohit et al. (2009), Kar et al. (2012) and Abdel-barr et al. (2012) respectively. Similar observations were also reported

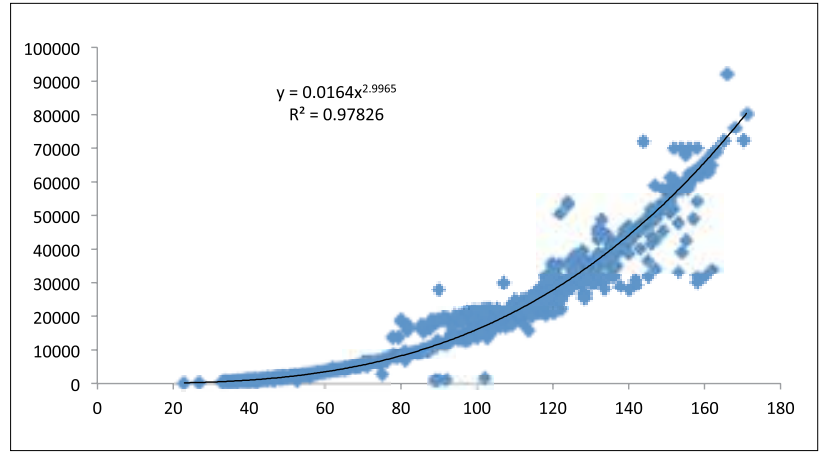

Fig. 8. Pooled Length-Weight relationship of Thunnus albacares

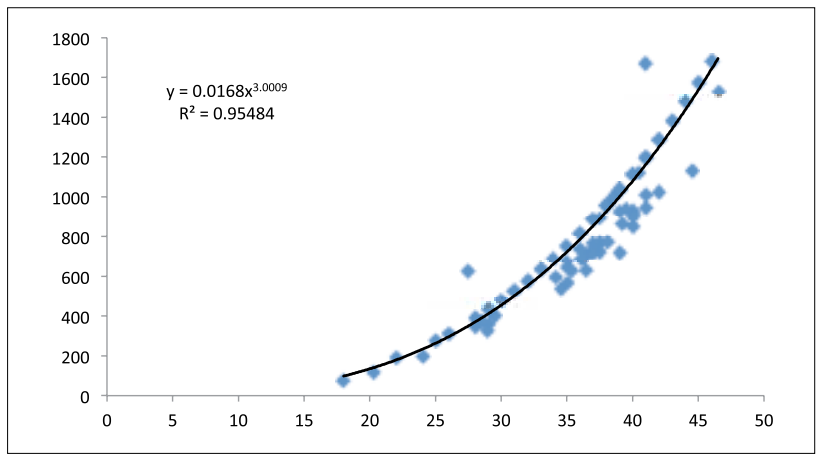

Fig. 9. Length-Weight relationship for indeterminates of Thunnus albacares

in the present study, where smaller individuals were caught in trawlnets and gillnets and larger ones in hooks and lines.

The length weight relationship indicated isometric growth and the value of ' $b$ ' was close to 3 , similar to the values obtained by earlier workers. Length-weight relationships were almost similar between males, females and indeterminates and therefore a common relation was arrived at by pooling the relation for males, females and indeterminates ( $p$ value $<0.05$ ). Similar exponent values varying from 2.74 to 3.24 were reported by several authors from different sectors. Madan Mohan et al. (1985) recorded the exponent value to be as 2.961 for males and 3.010 for females from Minicoy waters. Sivadas (2009) reported length weight relationship of Thunnus albacares from Minicoy waters and observed the ' $b$ ' value as 2.939 indicating isometric growth for the species. From the long line catches of different sectors of Indian EEZ, John and Reddy, 1989; Sudarshan et al., 1991; John and Sudarshan, 1993; John, 1995 and Pandian et al., 2007 recorded the ' $b$ ' value as $2.805,2.849,2.831,2.756$ and 2.908, respectively. Rohit et al. (2009) estimated 'b' values of 3.12 from the Visakhapatnam coast of Andhra Pradesh and 2.976 for the eastern Indian coast in 2012. Length-weight relationship is influenced by changes in ecosystem and in biological phenomena like maturity stages, feeding behaviour and competition for food. The peak landings of size classes $41-50 \mathrm{~cm}$ and $111-120 \mathrm{~cm}$ in the present study are however, 
different from earlier studies. Highest mean length recorded earlier from the same area was during November-January (Rohit et al., 2009), which differed from October- April which was observed during the present study.

\section{Acknowledgements}

The authors are thankful to the Director, CMFRI for encouragement and facilities provided.

\section{References}

Abdel-Barr, M., A. El-Sayed and A. Al-Oraimi. 2012. Length-frequency, Yield and Biomass per Recruit Analysis for Yellowfin Tuna, Thunnus albacares (Bonnaterre 1788) in the Arabian Sea off Oman. Asian Fish Sci., 25: 290-302.

Abdussamad, E. M., N. G. K. Pillai and T. S. Balasubramanian. 2008. Population characteristics and fishery of yellow fin tuna, Thunnus albacares landed along the Gulf of Mannar coast, Tamil Nadu, India. Egypt. J. Aquat. Res., 34(2): 330-335.

Beverton, R. J. H. and S. J. Holt. 1957. On the dynamics of exploited fish population. Fish. Invest, II (19), Ministry of Agriculture, Fisheries and Food, London, U. K., 533 pp.

John, M. E. and K.S.N. Reddy. 1989. Some considerations on the population dynamics of yellowfin tuna, Thunnus albacares (Bonnaterre) in Indian seas. Studies on fish stock assessment in Indian waters. Foreign Service Institute Special Publication, 2: 33- 54.

John, M. E. and D. Sudarsan. 1993. Fishery and Biology of yellowfin tuna occurring in oceanic fishery in Indian seas. In: Sudarsan, D. and M. E. John (Eds), Tuna Research in India: p 39-61.

John, M. E. 1995. Studies on yellowfin tuna, Thunnus albacares (Bonnaterre, 1788) in the Indian seas, Ph.D. thesis submitted to Bombay University: 258 pp.
Kar, A. B., L. Ramalingam, K. Govindaraj and G. V. A. Prasad. 2012. Study of the growth and population parameters of Yellowfin tuna (Thunnus albacares) in the Andaman and Nicobar waters based on the length frequency data. Report of the Fourteenth Session of the IOTC Working Party on Tropical Tunas (WPTT), 2012, Mauritius, p. 24-29.

Le Cren, E. D. 1951. The length weight and seasonal cycle in gonad weight and condition in the perch (Perca fluviatilis). J. Anim. Ecol., 20: 201-219.

Madan, Mohan and K. K. Kunhikoya. 1985. Length-Weight Relationship of Skipjack, Katsuwonus pelamis (Linnaeus) and Yellowfin tuna Thunnus albacares (Bonnaterre) from Minicoy waters, CMFRI Bulletin, 36: 122-137.

Pandian, P. P., A. B. Kar, M. K. Sinha and S. K. Pattnayak. 2007. Observation on the distribution and abundance of tuna resources in the Exclusive Economic Zone (EEZ) of Andaman \& Nicobar Islands. Zool. Surv. India, National Symposium on Conservation and Valuation of Marine Biodiversity: p 287-299.

Pillai, P. P., K. P. Koya, N. G. K. Pillai and A. A. Jayaprakash. 1993. Fishery and biology of yellowfin tuna occurring in the coastal fishery in Indian seas. In: Sudarsan, D. and John M. E. (Eds.) Tuna Research in India, p 23-38.

Rohit, P. and K. Rammohan. 2009. Fishery and Biological Aspects of Yellowfin Tuna Thunnus albacares along Andhra Coast, India. Asian. Fish. Sci., 22: 235-244.

Rohit, P., G. S. Rao and K. Rammohan. 2012. Age, growth and population structure of the yellowfin tuna Thunnus albacares (Bonnaterre, 1788) exploited along the east coast of India. Indian J. Fish., 59 (1):1-6.

Sivadas, M. 2009. Status of tuna fishery in Minicoy, Lakshadweep. In: Pillai, N. G. K. Menon, N. G., Pillai, P. P. and U. Ganga (Eds.), Management of Scombroid Fisheries. p. 62-68.

Snedecor, G. W. and W. G. Cochran. 1967. Statistical Methods Oxford and IBH publishing Co. New Delhi. 593 pp.

Sudarsan, D., M. E. John and K.N.V. Nair. 1991. Some biological considerations of the yellowfin tuna, Thunnus albacares (Bonnaterre) taken by longline gear in the Indian EEZ. Workshop on Stock assessment of Yellowfin Tuna in the Indian Ocean: TWS/91/11: p. 18-26.

Thomas, J., S. Venu and B. M. Kurup. 2003. Length-weight relationship in some deep sea fish inhabiting the continental slope beyond $250 \mathrm{~m}$ depth along the west coast of India. NAGA, 26: 17-21. 